\title{
Economic incentives and the epidemiological indicators can contribute to the reduction of occupational hazards?
}

\author{
Maria Luiza C. Comper ${ }^{\mathrm{a}, \mathrm{b}^{*}}$ and Rosimeire S. Padula ${ }^{\mathrm{b}}$ \\ ${ }^{a}$ Discipline of Physical Therapy, União Metropolitana de Ensino e Cultura, Av J.S.Pinheiro,Itabuna, Brazil \\ ${ }^{b}$ Masters in Physical Therapy Program, Universidade Cidade de São Paulo, R. Cesário Galeno, 448, São Paulo, \\ Brazil
}

\begin{abstract}
This article intends to discuss the interfaces of Decree No. 6042 and the adoption of its guidelines as a strategy to reduce the occupational hazards.
\end{abstract}

Keywords: Brazilian Government, Tax policy, Occupational Risks,

\section{Introduction}

Brazilian Government, concerned with the significant number of morbidity and mortality in the workplace, discussed and proposed a National Policy Occupational Health and Safety. This policy provides guidelines and strategies that should guide the plans and actions for the worker health and safety, including: the establishment of a tax policy that favors companies with lower rates of work diseases and accidents and the presumed nexus technical epidemiological $^{[1]}$. This strategy was regulated by Decree No. 6042 which establishing the implementation, monitoring and evaluation of the Accident Insurance Factor (AIF) and the Nexus Technical Epidemiological (NTEP) ${ }^{[2]}$. Therefore, this article intends to discuss the interfaces of Decree No. 6042 and the adoption of its guidelines as a strategy to reduce the occupational hazards.

\section{Methods}

The study is based on articles available in databases (MEDLINE, LILACS, PUBMED, SCIRUS, EMBASE, CINAHL), legal documents and texts of official sites.

\section{Results}

The methodology regulated by Decree No. 6042 meets the definition and epidemiological validity and represents an advance in the Health and Safety policies of the worker ${ }^{[3]}$. The calculation of taxes to the Worker's Compensation Insurance (WCI) is to be based on AIF is built into the rates of frequency of accident benefits set by NTEP. The statistical results of the social security, during 2008 revealed that there was an increase in reporting of MSDs records equivalent to $893 \%$ when compared to data recorded between 2006 and $2007^{[5]}$. Economic incentives, represented by strategies such as reduced insurance premiums and lower taxes were identified as the most effective for investments in shares of Occupational Health and Safety (OHS), to generate direct impacts on business budgets. However, there are still some elements of fragility, inherent to own three methods, which can negatively influence the implementation of improvements to reduce occupational hazards ${ }^{[4]}$.

*Corresponding author. E-mail: marialuizacaires21@hotmail.com 


\section{Discussion}

Considering all the issues raised above, it is believed that this economic stimulus will cause firms to invest in shares of health promotion and prevention of accidents and diseases, and therefore reduce the number of accidents and occupational diseases. It is noteworthy, however, that the effectiveness of incentives depends on other factors, such as the seriousness of the companies in the implementation of actions, government oversight and sensitivity to distinguish the performance of organizations, encouraging change in attitudes and behavior in the performance of SST. In this sense, it is necessary to combine this with other instrument of collective action of workers, businessmen and politicians in search of working conditions healthier and safer.

\section{References}

[1] Brasil. Política Nacional de Segurança e Saúde do Trabalhador. In: Ministério do Trabalho, editor. Brasília: MTE/MPS; 2004.

[2] Brasil. Altera o Regulamento da Previdência Social, aprovado pelo Decreto n. 3.048, de 6 de maio de 1999, disciplina a aplicação, acompanhamento e avaliação do Fator Acidentário de Prevenção - FAP e do Nexo Técnico Epidemiológico, e dá outras providências. (2007).

[3] Santana VS. Bases Epidemiológicas do Fator Acidentário Previdenciário. Revista Brasileira de Epidemiologia. 2005;8(4):440-53.

[4] Silva RG, Fischer FM. Incentivos Governamentais para Promoção da Segurança e Saúde no Trabalho: em busca de alternativas e possibilidades. Saúde Sociedade São Paulo. 2008;17(4):11-21.

[5] Souza NS, Santana VS, Oliveira PR, Branco AB. Doenças do trabalho e benefícios previdenciários relacionados à saúde, Bahia, 2000. Revista Saúde Pública. 2008;42(4):630-8. 